\title{
Uma cultura para Shakespeare e Beethoven
}

\author{
Rodrigo Juventino Bastos de Moraes*
}

\begin{abstract}
Resumo: É conhecida a importância fundamental de Shakespeare para as artes e para o debate estético alemão nos séculos XVIII e XIX. O drama de Shakespeare foi apontado entre os alemães como uma verdadeira revolução cultural, o exemplo do gênio original em que deviam se mirar caso quisessem se desvencilhar das amarras do classicismo francês e desvendar sua própria originalidade. Este artigo pretende mostrar como Nietzsche dá continuidade a essa leitura ao apontar o drama shakespeariano também como um acontecimento que tinha a importância de uma revolução cultural entre os alemães. Shakespeare era o "Sócrates musicante", o sinal do despertar do gênio trágico em solo alemão.
\end{abstract}

Palavras-chave: Nietzsche, Shakespeare, Sócrates, musicante, Sófocles.

* Universidade de São Paulo, São Paulo, São Paulo, Brasil.

ORCID https://orcid.org/0000-0003-4212-563X

Correio eletrônico: rodrigojb.moraes@gmail.com 
Moraes, R. J. B.

\section{Introdução: uma revolução chamada Shakespeare}

Em seu texto de juventude, Para o dia de Shakespeare, Goethe conta como tinha sido importante para ele ter se deparado com a obra do dramaturgo inglês e como esse encontro teria marcado sua vida para sempre. A razão é que, por meio de Shakespeare, era como se tivessem dado luz a um cego de nascença depois de muitos anos de trevas: "aos poucos aprendi a enxergar e tenho de dar graças ao meu gênio reconhecido, se ainda hoje sinto vivamente o que ganhei" (Goethe, 2000, p.66). A descoberta do dramaturgo inglês também é descrita por Goethe como uma forma de despertar no encontro do protagonista de seu romance $O$ s anos de aprendizado de Wilhelm Meister com a obra de Shakespeare. Aspirante a dramaturgo na trupe do Melina, seu herói lê pela primeira vez a obra de Shakespeare no cômodo mais retirado do castelo do barão por ocasião de uma peça que seria encenada em homenagem ao príncipe que por lá faria estadia. No recesso do quarto, Meister se move "no universo shakespeariano" e essa experiência parecia a ele como um despertar: seu espírito se expandia qual um acontecimento mágico, nele se agitavam "mil sensações e faculdades das quais não havia tido nenhuma noção, nenhuma ideia". (Goethe, 2006, p.188-189).

Todas essas impressões novas e inauditas que inundavam o espírito de Meister nos remetem à genialidade do dramaturgo inglês. A experiência de leitura de Shakespeare remetia Meister ao inteiramente original de seus dramas, pois o poeta inglês produzia de forma totalmente autônoma, sem se dobrar a fórmulas ou regras preestabelecidas. O que explicava a perplexidade do herói do romance de Goethe: esse poetar, retirado exclusivamente de suas mais primárias forças naturais, despertava Meister para o sentimento de sua própria genialidade. Esse era justamente o poder que Shakespeare também tinha aos olhos de Lessing, e por isso o autor de Hamlet devia ser visto entre os alemães com a importância de uma verdadeira revolução cultural. Com Shakespeare, pensava Lessing, estava lançada uma 
cruzada contra as amarras que o classicismo francês tinha imposto ao teatro alemão e por isso o dramaturgo inglês devia ser visto como exemplo da vitalidade do gênio original frente às regras enfadonhas e estéreis do teatro de Corneille e Racine. A exemplo de Shakespeare, o gênio alemão podia agora ser incendiado, podia despertar para o sentimento de sua própria originalidade; pois, na visão de Lessing, "o gênio só pode ser inflamado por outro gênio, e com maior facilidade por um que pareça dever tudo à natureza e que não intimide pelas árduas perfeições da arte" (Lessing, 1991, p.110). Nesse mesmo sentido, Kant vai escrever em sua terceira Crítica que a produção do artista de gênio, por ter sua origem exclusivamente em suas próprias forças e se extinguir também com elas, não serviria como exemplo a ser imitado. Por meio dela, no entanto, um outro gênio poderia ser despertado para "o sentido de sua própria originalidade, exercitando na arte uma tal liberdade da coerção da regra, que a própria arte obtém por este meio uma nova regra, pela qual o talento mostra-se como exemplar" (Kant, 2010, p.163-164). Nesse contexto é que a obra genial de Shakespeare será vista entre os alemães como uma verdadeira revolução cultural, como um despertar para o sentimento de sua própria originalidade, do seu próprio gênio.

No presente artigo pretendemos mostrar que, assim como na juventude de Goethe, o drama shakespeariano será visto também pelo jovem Nietzsche com a importância de uma verdadeira revolução cultural. Em Shakespeare, é como se o sentido da originalidade alemã fosse finalmente iluminado, pois seu drama tinha posto em curso um acontecimento paralelo ao Renascimento latino, tinha marcado uma ruptura com o espírito alexandrino que iria alcançar seu auge no drama musical de Wagner. No drama shakespeariano, o sentimento do trágico e a mística germânica voltam então a exigir das produções da cultura o primado dos profundos impulsos vitais e das forças telúricas e idealistas da arte aprisionados pela visão teorética e otimista do mundo moderno que gerou sua cultura do jornal e da 
Moraes, R. J. B.

arte alexandrina da moda e do luxo ${ }^{1}$. Rebentos esses do processo de racionalização ocidental que, desde a Grécia antiga de Sócrates, evolui até a era de "mundanização extrema" [äusserster Verweltlichung] (GT/ NT 21, KSA 1.133) ${ }^{2}$ de impulsos políticos do utilitário e esvaziado mundo burguês moderno. $\mathrm{O}$ drama shakespeariano tinha revivido em solo moderno o antigo espírito dos trágicos gregos e, em vista dessa verdadeira revolução, é que o filósofo reivindica entre os alemães a busca por "uma cultura para Shakespeare e Beethoven", como o verdadeiro problema alemão em sua luta pela "libertação do mundo latino (Befreiung vom Romanismus)" que em seu tempo encontrava no idealismo de Schiller e no drama musical de Wagner e de seus precursores (NF/FP 1871, 9[147], KSA 7.329).

Nesse sentido se pode afirmar, como afirma Katie Brennan (2004, p. 109), que embora tenha desistido desse propósito em sua primeira obra publicada, constava entre as intenções de Nietzsche mostrar como o drama de Shakespeare "servia de elo entre o espírito dos grandes dramaturgos gregos antigos e Wagner". E, de fato, Nietzsche por vezes vai apontar o drama de Shakespeare, no mesmo sentido que o faz em relação à Reforma, ${ }^{3}$ como símbolo de

1 A “moda" (Mode), expressão utilizada por Nietzsche, remete à noção empregada por Wagner em vários momentos de sua obra escrita para exprimir um fenômeno artístico efêmero, supérfluo, nascido não de uma necessidade da Natureza, de uma essência interior, mas de uma necessidade artificial, exterior. A moda, como Wagner vai defender em sua Die Kunstwerk der Zukunft, era produto da racionalização que colocou o pensar no centro do processo de desenvolvimento da cultura em detrimento do sensível e converteu a natureza no acessório: "se o espírito é o incondicional, é causa sui, é o fim da história, então "a vida é o arbitrário, [..] todas as carências humanas passam a ser luxo", e o luxo, o que se carece. Por isso a moda é "esse estimulante artificial que desperta uma carência não-natural onde a carência natural não existe" (Wagner, 2003, p.31). A ópera, arte da "ganância visual", (die blosse Augenbegierde) como Wagner aponta dessa vez em seu livro Oper und Drama, era o exemplo dessa arte correspondente às necessidades artificiais e exteriores da moda - um produto da alienação burguesa, do escravo moderno do luxo e do supérfluo (Wagner, 1869, p.124-125). Moda, por fim, que exerceu seu domínio sobre os alemães e cujas leis são ditadas pelo gosto latino da França, há duzentos anos, "o único fermento produtivo da formação europeia” (Wagner, 2000, p.85).

2 Para a citações d'O Nascimento da Tragédia, utilizo a tradução de Jacob Guinsburg.

30 "espírito alemão viril, sério, melancólico, duro e audaz", como Nietzsche escreve na conferência sobre o futuro das escolas alemãs, que havia se conservado são e salvo desde a época da Reforma, no "espírito de Lutero, filho de um mineiro" (BA/EE, KSA 1.749). Nesse particular, a influência

48 | Cad. Nietzsche, Guarulhos/Porto Seguro, v.42, n.3, p. 45-67, setembro/dezembro, 2021. 
um acontecimento paralelo ao Renascimento latino, como uma libertação do mundanismo alexandrino, como uma ruptura da natureza interior e mística do alemão congenial ao espírito dos trágicos gregos pré-platônicos: "os latinos como artistas foram até agora decisivos [culturalmente] à toda a posteridade", mas só "o espírito alemão originário de Shakespeare, Bach, etc., se emancipou deles" (NF/FP 1871, 9[143], KSA 7.327). Nesse sentido, Shakespeare é já uma ponte em direção a Wagner, cujo drama musical, como renascimento da tragédia grega de Ésquilo, levava essa luta ao limite. Como escreve Nietzsche na última de suas Extemporâneas, Wagner era o "contraAlexandre (Gegen-Alexandern)" por excelência (WB/Co. Ext. IV, KSA 1.447).

Embora faça essa observação, Brennan, no entanto, não avança nela. Nesse mesmo artigo, a autora defende que Nietzsche restringiu suas reflexões sobre Shakespeare às anotações privadas e, no fim, em sua primeira obra publicada, declinou de incluir maiores considerações sobre Shakespeare em razão do compromisso assumido com a causa wagneriana. Essa é a conclusão a que chega Brennan partindo da premissa de que o essencial da reflexão do drama shakespeariano nos primeiros escritos de Nietzsche se concentra na personagem Hamlet. O herói da peça homônima de Shakespeare representava uma máscara por meio da qual Dionísio se revelava em toda sua potência e se mostrava em equilíbrio com o mundo cênico de Apolo sem se valer da música, o que aparentemente tornava o drama shakespeariano mais "compatível com a tragédia grega antiga em comparação com outros artistas modernos, como Wagner" (Brennan, 2014, p.127). Algo que para Brennan (2014, p. 122) entrava em contradição com

\footnotetext{
de Wagner parece inquestionável: Nietzsche entendia, como o compositor, a Reforma como um acontecimento paralelo ao Renascimento latino que revelava a insurgência do espírito alemão contra o mundo alexandrino moderno. Em seu texto escrito em 1865, Was ist deutsch, reeditado e publicado no Jornal mensal Bayreuther Blätter, fundado em 1878 por Hans von Wolzogen e voltado para os visitantes dos festivais de Bayreuth, Wagner aponta a Reforma como um acontecimento histórico alemão que tem origem no desejo de libertação do mundanismo Católico centralizado e que devia ser interpretado como um passo em direção a uma identidade alemã mais honesta (Wagner, 1878, p.32).
} 
Moraes, R. J. B.

a doutrina central do seu primeiro livro, segundo a qual a "música é o único veículo por meio do qual o dionisíaco pode ser apresentado" para o efeito total da tragédia. A partir de Hamlet, Nietzsche estaria sugerindo que Shakespeare tinha mostrado como edificar o drama sem necessidade de se valer da música. E isso como que revelava uma contradição para a exposição de $O$ nascimento da tragédia que obrigou Nietzsche a deixar de lado maiores considerações sobre Shakespeare para não desagradar Wagner e não ferir o compromisso de ambos com a filosofia de música de Schopenhauer.

A abordagem do drama shakespeariano nos primeiros escritos de Nietzsche não está, no entanto, centrada na personagem Hamlet, como afirma Brennan; mas na assunção de Shakespeare como personificação do "Sócrates musicante" em solo moderno, como por vezes o filósofo defende nas anotações póstumas. Algo que o presente artigo, na primeira seção, pretende mostrar a partir de um enquadramento da obra do dramaturgo inglês como uma espécie de consumação de Sófocles ("Shakespeare Vollendung des Sophocles") (NF/FP 1871, 9[132], KSA 7.322). Percorrido o caminho que nos leva a esclarecer esse ponto, pretendo propor, na última seção, uma alternativa à conclusão de Brennan: em $O$ nascimento da tragédia, Nietzsche deixou de incluir maiores considerações a respeito do papel do drama shakespeariano para a revolução do espírito trágico alemão não por receio de ofender Wagner ao deixar claro, segundo o pretenso espírito de sua doutrina, a proeminência de Shakespeare na relação com a tragédia antiga se comparado ao drama wagneriano, como argumenta Brennan em seu artigo. Mas porque Nietzsche provavelmente não quis repetir o que nesse particular Wagner já tinha desenvolvido em Beethoven, panfleto que escreve e publica no final de 1870, pouco mais de um ano antes do primeiro livro de Nietzsche sair do prelo. 


\section{Shakespeare: o Sócrates musicante}

Queremos defender o primeiro ponto a partir de uma carta de Schiller a Goethe do final de 1797 que Nietzsche transcreve em anotação de 1871, ano de redação de $O$ nascimento da tragédia (NF/FP 1871, 9[77], KSA 7.302). Nessa carta, Schiller revela que a genuína admiração que nutria pela obra de Shakespeare se devia especialmente à leitura de Ricardo III, uma das mais "sublimes tragédias" que até então conhecera. $O$ modo desenvolto com o qual o dramaturgo inglês sabia encontrar em todas as ocasiões o aspecto poético "no material mais grosseiro" lhe parecia surpreendente, assim como a destreza que demonstrava ao representar aquilo que não podia ser representado. Nas palavras de Schiller: "a arte de utilizar os símbolos, quando a natureza não se pode representar, [...] nenhuma outra obra de Shakespeare me recorda tanto a tragédia grega" (Goethe \& Schiller, 1881, p.332).

Para Nietzsche, compreender a importância revolucionária do drama de Shakespeare exigia justamente elucidar a equiparação feita nesses termos por Schiller entre a tragédia grega antiga e o drama shakespeariano: a prerrogativa de produzir imagens do que não se pode representar. Algo que o filósofo vai fazer a partir de um paralelo entre Shakespeare e a tragédia antiga canônica de Sófocles, conforme suas anotações do segundo semestre de 1870. Além de ser um período frugal para as ideias que culminam n'O nascimento $d a$ tragédia, esse ano é também o período em que Nietzsche concilia suas reflexões filosóficas com as atividades de professor de filologia recém-egresso na Universidade da Basileia. Nesse mesmo semestre, Nietzsche pretendia dar um curso sobre Édipo rei para seus alunos do Pädagogium, e nas anotações de aula que sobreviveram à época, suas reflexões sobre a tragédia de Sófocles já aparecem em paralelo com as reflexões sobre o drama de Shakespeare. Esse período, em que se concentram as notas de Nietzsche sobre Shakespeare, também revela, como mostraremos adiante, que o filósofo escrevia sobre o 
Moraes, R. J. B.

dramaturgo inglês já sob influência do contato travado com Wagner. Concomitantemente às anotações de Nietzsche para o curso do semestre de verão de 1870, fervilhavam as ideias de Wagner que aparecerão amadurecidas em seu texto escrito em homenagem ao centenário de Beethoven lido em setembro do mesmo ano.

Esse paralelo entre Shakespeare e Sófocles será pensado por Nietzsche, como mostra uma anotação de 1871, enquadrando o dramaturgo inglês como uma espécie de consumação de Sófocles ("Shakespeare Vollendung des Sophocles") (NF/FP 1871, 9[132], KSA 7.322). Em uma anotação enigmática de 1870, Nietzsche escreve que "o dionisíaco é puramente absorvido em imagens" em Shakespeare e, com isso, "o abandono do coro estava completamente justificado" (NF/FP 1870, 7[134], KSA 7.193). Essa absorção da música em imagens é o que fazia do poeta moderno, segundo Nietzsche, um "consumador" do que Sófocles tinha dado início na Antiguidade. Se vamos às anotações de aula para o curso sobre Édipo rei, é possível compreender o que Nietzsche pretendia dizer com isso. Em Sófocles, ocorre "um triunfo do pensamento trágico e uma superação do culto dionisíaco de Ésquilo", justamente o que distinguia o autor de Édipo rei de seu mestre, segundo Nietzsche constata em outra anotação do mesmo ano (NF/FP 1870, 7[174], KSA 7.207). O que significa dizer que, distintamente de Ésquilo, Sófocles tinha convertido a música em discurso, ou o pensamento tinha se tornado trágico pela primeira vez. E esse fato como que deixava o tragediólogo a meio caminho de Eurípedes que buscava "alcançar o efeito ditirâmbico", "obter a todo custo com a poesia o efeito da música” (NF/FP 1870, 7[129], KSA 7.192).

Ainda em suas anotações de aula, Nietzsche argumenta que a tragédia de Sófocles ocupava uma posição bem marcada no conflito entre Apolo e Dionísio que se desdobra na própria evolução do drama antigo: sua obra ocupava, no curso do desenvolvimento da tragédia, um médium numa espécie de "progressão da consciência". E isso podia 
se notar pela própria crítica de Sófocles aos seus contemporâneos: Ésquilo fazia "o melhor, sem o saber", enquanto que Eurípedes era todo consciência e por isso como que se lhe opunha no outro extremo (Nietzsche, 2014, p.83). Ou seja, Sófocles estava entre a obra completamente inconsciente de Ésquilo e a totalmente consciente de Eurípedes. Na obra de Ésquilo, o instinto era sempre quem guiava e sua tetralogia era "o cordão umbilical por meio do qual a tragédia estava ligada ao ditirambo, sua mãe" (I Nietzsche, 2014, p.84). Com Sófocles, no entanto, o lógos ganha força e o pensamento se torna trágico: "Sófocles caminha para além da trilha de Ésquilo: até então, era o instinto artístico da tragédia que a impulsionava; agora é o pensamento" (Nietzsche, 2014, p.84). Ou seja, para Nietzsche, Sófocles era o poeta do pensamento trágico.

O que teria convertido as imagens musicais de Ésquilo em pensamentos musicais de Sófocles? Na tragédia de Sófocles, o coro trágico tinha sido despotencializado com o acréscimo do terceiro ator: com essa providência se introduz no drama "o virtuosismo, e por isso o lógos se tornou cada vez mais protagonista" (Nietzsche, 2014, p.88). ${ }^{4}$ Isto é, a massa coral que antes excitava as páthe, os "padecimentos", se valendo de uma cena mínima, cede então parte de sua força patética à cena ampliada, à dialógica, ao lógos, com o incremento do terceiro ator. Essa providência desloca a preponderância do coro musical para a cena - para a ação e o diálogo - e o lógos fortalecido exige que daí em diante as paixões sejam excitadas pelo virtuosismo do ator que agora assume o primeiro plano. Mesmo a despeito de ter enfraquecido o poder da música - que para Nietzsche, como se sabe, é a força produtora do instinto na tragédia - com essa providência, Sófocles, no entanto, não o tinha feito em prejuízo da sabedoria trágica como ocorrerá com a tragédia de Eurípedes, na qual o diálogo

4 Informação que consta na Poética de Aristóteles: "Ésquilo foi o primeiro a elevar o número de atores de um para dois; ele diminuiu as partes relativas ao uso do coro e tornou o diálogo [lógos] apto a desempenhar o papel de protagonista. Sófocles elevou para três o número de atores e introduziu a cenografia”. (Aristóteles, 2015, p.63). 
Moraes, R. J. B.

é levado ao paroxismo e se converte em dialética. Assim, mesmo despotencializado a música ao conferir maior amplitude à cena, ao diálogo em prejuízo do coro, o próprio discurso se converte em música com o uso da linguagem simbólica do mito na tragédia de Sófocles. Apesar de conferir maior relevância ao mundo apolíneo da cena, da ação e do diálogo, o autor de Édipo Rei soube articular o pensamento à sabedoria trágica em uma trama patética. ${ }^{5}$

Apesar da degradação do coro pelo avanço da força toda poderosa do impulso apolíneo dos gregos, com a consequente ampliação do lógos e a potencialização do diálogo, na tragédia de Sófocles, entretanto, ojogo fraterno entre os dois impulsos artísticos da Natureza, Dionísio e Apolo, não tinha sido de todo desfeito. Nela, o instinto (coro musical) produzia em imagens (cena) se valendo da linguagem dialógica do épos tomada de Homero - o pensamento se tornava trágico com a encenação do mito trágico. Em Sófocles, as disputas e conclusões constitutivas do pensamento, da dialógica, se articulavam à certa beleza e interiorização musicais, ainda que de modo precário. O que significa dizer que as forças telúricas interiores e instintivas da Natureza produziam suas imagens externas para a consciência desperta, nas formas de apercepção do mundo exterior e, por isso, para Nietzsche, "a dissolução da música em um mito" constituía a forma mais objetiva de definir o trágico" (NF/FP 1871, 9[125], KSA 7.320). Essa expressividade da Ideia do mundo, da transposição do infinito do coro no finito do épos constitutivo do mito trágico, é o que firmava a "aliança fraterna" entre os dois impulsos da natureza que para Nietzsche deu origem à tragédia e que fazia do drama musical antigo ponto alto da expressão, pois mantinha de pé o jogo [Spiel], a "aliança fraterna" entre a verdade trágica do bárbaro

5 A partir da cena, como escreve Nietzsche em $O$ nascimento da tragédia, fala a clareza e a firmeza da configuração épica de Apolo, não mais a força telúrica e informe da música: "Dionísio não fala mais através de forças, mas como herói épico, quase com a linguagem de Homero”. (GT/NT 8, KSA 1.64).

54 | Cad. Nietzsche, Guarulhos/Porto Seguro, v.42, n.3, p. 45-67, setembro/dezembro, 2021. 
do oriente, o instinto dionisíaco, e a beleza e moderação transfigurado grega do ethos clássico de Homero (GMD/DM, KSA 1.567).

Acontece, entretanto, que essa aliança é desfeita pela hybris do todo poderoso espírito apolíneo dos gregos quando a forma do pensamento, na dialógica do épos, é levado ao paroxismo ao se converter em disputa dialética. ${ }^{6}$ Precisamente o que tinha ocorrido quando a dialógica do épos é dramatizado como dialética com o teatro de Eurípedes. Ao levar a dialética para a tragédia, Eurípedes tinha produzido um novo tipo de arte que já não tinha mais nenhuma relação com os impulsos artísticos da Natureza: a tragédia de Eurípedes já não era nem apolínea, nem dionisíaca - era socrática. Um novo tipo de arte que conferia toda sua força a um desmedido impulso político e à ideia moral de que a arte poderia ser um arremedo de pedagogia de massa, que pela força do poder da lógica e do controle racional dos afetos se poderia corrigir a existência. Essa nova arte, vai dizer Nietzsche, "inartística" (ausserkiunstlerischen) que fez Eurípedes se jactar do seu feito: com ele, acreditava o próprio tragediólogo, a sabedoria finalmente tinha chegado à massa quando esta sobe ao palco e se vê raciocinando e agindo bem em suas tragédias (GT/NT 11, KSA 1.77).

Isso mostra que a forma figurativa e dialógica do épos apolíneo, se levada ao limite, acaba por aprisionar a atividade produtiva da Natureza, a força infinita da música; acaba, portanto, por encarcerar o instinto. ${ }^{7}$ As reformas de Eurípedes para Nietzsche encarnam a

6 "Só uma excessiva preponderância do apolíneo provocou o fim da tragédia [...]" (NF/FP 1871, $9[10]$ KSA 1.276).

7 Nas anotações de aula para o curso ministrado ente 1871-6 sobre os diálogos de Platão, Nietzsche escreve que, para curar o ceticismo desesperado de seu discípulo, Sócrates teria antes envenenado Platão com respeito à efetividade e apontado em seguida a redenção numa espécie de ódio à Natureza que nele seu mestre lhe tinha incutido. Nesses termos se compreende o que Nietzsche quer dizer com "aprisionamento do instinto" com o advento do socratismo. A natureza, para Sócrates, era a fonte de todo erro, a aparência das coisas, um inconveniente que podia ser corrigido pelo reino da ideia, do pensamento puro. $\mathrm{O}$ ódio à Natureza também se expressa na censura moral que Sócrates também transmitiu a Platão: “o desprezo e o ódio de Sócrates dirigidos contra a realidade eram antes de tudo um combate contra a realidade de todas a mais próxima, aquela que importuna o pensador, a 
Moraes, R. J. B.

tendência da nova cultura socrática, um desdobramento do processo de racionalização grego como espelhamento da disputa secularizada da ágora que adentra ao desenvolvimento do drama antigo no momento em que a tragédia confere maior acento à dialética em prejuízo da música. Ao introduzir "a dialética, o tom dos tribunais de justiça, no diálogo", diz Nietzsche, vemos à qual consequência desagradável Eurípedes induziu a arte dramática, pois, o que ele conseguiu com suas reformas foi mutilar o que antes era um todo na tragédia de seus predecessores. Como consequência de suas reformas, se separaram desde então "de modo antinatural o coração e o entendimento, a música e a ação, o intelecto e a vontade, cada parte separada se atrofia. E assim se originou a música absoluta e o drama familiar, a partir do desmembramento do drama musical dos antigos" (NF/ FP 1869, 1[49], KSA 7.25). Desde a transposição euripidiana da dialética para a tragédia, já se expressava aos poucos a cisão do homem pelo avanço do impulso formal que aprisionava a força mística da música e convertia toda a antiga simbologia da tragédia em uma forma secularizada de drama "burguês" naturalista.

Isso tudo, entretanto, nos devolve a Shakespeare. O avanço do impulso socrático da dialética que deu fim ao caráter totalizante que reinava na antiga tragédia, na qual instinto e beleza se mantinham em

saber: carne e sangue, cólera, paixão, voluptuosidade, ódio". Toda aversão que Sócrates sentia pela opacidade da natureza em constante devir, aos sentidos e ao corpo que induzem ao vício, tudo isso transmitiu a seu discípulo: a doxa de seus contemporâneos, disfarçada de sabedoria, era produto do éthos homérico, da mentalidade do mito, do sensualismo, dos vícios de uma religião desviante de Homero. (Nietzsche, 2019, p.189). Sócrates, por fim, ensinou a Platão a subverter o pessimismo e seu ceticismo desesperado ao convertê-lo a um novo tipo de "serenojovialidade grega", em uma fé otimista no poder emancipador da lógica e do controle racional dos afetos. Assim, não sendo mais a antiga serena grandeza apolínea do ingênuo Homero, essa serenojovialidade socrática se converte na que é própria a do homem teórico. Todo o aspecto escandaloso da natureza, o ciclo de geração e morte, o erro, a opacidade do conhecimento, o caráter deveniente da natureza e "desejante" do corpo, todos esses aspectos trágicos da existência não são mais cobertos com o véu da beleza, não são mais idealizados na figura dos deuses olímpicos. São vistos agora sob a ótica do teoreta otimista, cego em sua fé secular na individuatio, nos poderes da ciência, da razão, da política, da moral, do Estado de subtrair da existência tudo isso que vê como mero percalço a ser superado, a ser corrigido. E esse espírito socrático é que Eurípedes teria levado à tragédia.

56 | Cad. Nietzsche, Guarulhos/Porto Seguro, v.42, n.3, p. 45-67, setembro/dezembro, 2021. 
equilíbrio, nos revela o fundamento das formas artísticas modernas como o romance e o drama burguês. $\mathrm{O}$ drama moderno, desde sua origem, é "romance dramatizado" (Roman dramatisiert) $)^{8}$ cuja origem remonta às formas remotas do épos dramatizado secular não mais imantado pela força da Natureza, desde quando o mito trágico do drama musical grego se converte no naturalismo "burguês" da nova comédia. O drama de Shakespeare será herdeiro do épos dramatizado da comédia ática, como Nietzsche aponta n'O drama musical grego: "toda a estrutura e o caráter fundamental da tragédia de Shakespeare foram derivados de sua chamada nova comédia" e dela "se desdobraram, em descomunais espaços de tempo, o drama romano, a representação românico-germânica de moralidades e de mistérios". Conclui-se, pois, que "na forma externa da cena de Shakespeare não se pode desconhecer o parentesco genealógico com a nova comédia ática" (GMD/DM, KSA 1.515). ${ }^{9}$

Como dramaturgo moderno, Shakespeare é herdeiro do romance dramatizado do ponto de vista formal. No entanto, o drama de Shakespeare tinha uma peculiaridade e com ele se consumava o que a tragédia de Sófocles não pôde realizar com perfeição. Os heróis de Shakespeare, como vai apontar Nietzsche, faziam uso da dialética de modo completamente diferente: "sobre todos os seus pensamentos, suposições e conclusões vertem-se uma certa beleza e interiorização musicais, enquanto na tragédia grega mais tardia domina um dualismo de estilo muito precário, de um lado

8 Tanto a expressão quanto a ideia por detrás dela são retiradas do texto Oper und Drama: o drama shakespeariano, apontado por Wagner $(1869$, p.117) como o apogeu do drama moderno, nessa obra que tanta influência exerceu sobre Nietzsche, é uma adaptação do romance à cena: "Shakespeare [...] condensou o romance narrativo no drama, enquanto de alguma forma o traduzia para a representação no palco teatral". Wagner (1869, pp.148-151) classifica o drama moderno como "Roman dramatisiert", tendo sua origem numa imaginação descritiva dentro de um processo de secularização do mundo e da arte que, desde o mito despedaçado, perdeu seu caráter popular, sua conexão mística com o todo da natureza em direção a um realismo descritivo.

9 Para "o drama musical grego", utilizo a tradução: NIETZSCHE, F. A visão dionisíaca do mundo. Trad. e org. Marco S. Pereira \& Fernandes e Maria C. S. Souza, São Paulo: Martins Fontes, 2010, p.47. A partir de agora indicado como MSP/MS. 
Moraes, R. J. B.

o poder da música, de outro o da dialética" (ST/ST, KSA 1.546). ${ }^{10}$ Com essa constatação, o filósofo se aproxima do que Wagner tinha escrito a propósito de Shakespeare em Oper und Drama, obra que tanta influência exerceu para Nietzsche construir as ideias que vão culminar em $O$ nascimento da tragédia.

Nessa obra, Wagner diz que "a tragédia de Shakespeare até o presente supera categoricamente a grega, na medida em que ultrapassou totalmente a necessidade do coro na técnica artística". E a razão é que com ele o coro é "simplesmente dissolvido em indivíduos que participam pessoalmente da ação, que procedem por si próprios como o herói principal de acordo com a mesma necessidade individual de sua opinião e posição" [...] (Wagner, 1869, p.52-3). Corroborando essa ideia, Nietzsche vai dizer que não era a música e a dialética que se alternavam no drama de Shakespeare como ocorria no período de declínio da tragédia grega, mas o fundo dionisíaco da música é que se vale da cena e do diálogo para falar em símile de forma integral. $\mathrm{O}$ instinto irrompia no solo do racionalismo moderno secular e desmagificado e voltava a falar sua linguagem musical com Shakespeare. O que significa dizer que, com ele, o mito renascia em meio ao racionalismo moderno desmagificado, e por isso o dramaturgo inglês devia ser apontado como o "Sócrates que faz música".

\section{Em busca de uma cultura para Shakespeare e Beethoven}

Conforme uma das teses principais de seu primeiro livro publicado, para Nietzsche a tragédia tinha origem no ditirambo, isto é, no coro lírico de Dionísio que "vê em imagens os sofrimentos da individuação". A tragédia nasce no momento em que a cena é criada no centro do antigo círculo de cantores do ditirambo, como se o coro fosse o próprio produtor das imagens, como se imantasse com sua

10 Para a tradução de "Sócrates e a Tragédia, Cf. A visão dionisíaca do mundo, op. cit.

58 | Cad. Nietzsche, Guarulhos/Porto Seguro, v.42, n.3, p. 45-67, setembro/dezembro, 2021. 
sabedoria telúrica o mundo da cena. Como vai apontar em anotação de 1870, “a música, a dança, a lírica, são o simbolismo dionisíaco de onde nasce a visão. Excitação no fundo dos sentimentos em relação à projeção das imagens: entre as quais haverá uma afinidade natural" (NF/FP 1870, 8[7], KSA 7.222).

A capacidade que a música tem de produzir em imagens patéticas se deduz da própria sabedoria do "mito que fala em símiles acerca do conhecimento dionisíaco" (GT/NT §16, KSA 1.105). Aqui, embora se utilize do lógos e da dialógica, a lógica está totalmente proscrita e seu conteúdo patético não se deixa revelar nem às formas nem aos motivos do pensamento consciente. Não à toa que Eurípedes, em razão de sua intoxicação socrática, não podia sentir se mover em seu íntimo os motivos interiores da Natureza na tragédia quando descia o pano da individuationis por meio da excitação musical e da linguagem do mito. Por intoxicação socrática, Eurípedes se mostrava sempre aturdido com a tragédia de seus poetas predecessores: "quão duvidosa permanecia para ele a solução dos problemas éticos" para Eurípedes, quão enigmático era o coro e "questionável o tratamento dos mitos! Quão desigual a repartição de ventura e desventura! Mesmo na linguagem da tragédia antiga havia para ele muita coisa de ofensiva, ao menos enigmática" (GT/NT §11, KSA 1.80). Tendo origem no instinto, nos arcanos do inconsciente, nos motivos misteriosos e profundos da Natureza, a linguagem do mito revelava, pois, a passagem dos motivos internos à sua expressão externa em imagem e diálogo, de forma simbólica. Por isso nunca se tornava transparente no sentido de se deixar enquadrar por uma nitidez conceitual nem para o poeta, nem para o filósofo. O que significa que a sabedoria da música, inacessível ao pensamento, fazia com que o foco da cena estivesse em menor proporção na fala do que na ação.

Eis por que Shakespeare não só tinha algo em comum com o autor do Édipo rei, mas mesmo o tinha levado ao radicalismo: 
Moraes, R. J. B.

com o dramaturgo inglês se consuma o que Sófocles tinha iniciado quando a música é, então, completamente absorvida em imagem: "o nascimento do pensamento a partir da música se mostra apenas como uma sombra na concepção do mundo em Sófocles. Em Shakespeare temos, portanto, a consumação: autenticamente germânica: gerar as ideias a partir da música" (NF/FP 1871, 9[125], KSA 7.320). Nesse sentido, embora seu drama fosse inteiramente ação e diálogo, Shakespeare fazia música por meio de imagens e por isso podia ser apontado como o poeta do mais radical pensamento trágico - o próprio criador do mito moderno. No interior do drama moderno, a linguagem do mito reaparece de modo exemplar no Hamlet: na tragédia shakespeariana, a fala de Hamlet é mais superficial do que a ação e "quando Shakespeare proporciona ideias, são frequentemente uma imagem debilitada, e até intencionalmente destruída" (NF/FP 1869, [38], KSA 7.20). Não é, pois, a partir da palavra e da cadeia causal de ideias, mas da "visão e revisão aprofundadas do conjunto", do todo, "que se deve inferir aquela doutrina do Hamlet" (GT/NT §17, KSA 1.110) segundo a qual o conhecimento aniquila a ação, e a ação requer o véu da ilusão. Hamlet, como símbolo dessa sabedoria interior e mística, era certamente a prova de que em Shakespeare "o pensamento se adequou à música" (NF/FP 1871, 9[109], KSA 7.314). Nesse sentido, como Nietzsche anota em um fragmento de 1871, além de ser tão grego quanto Sófocles, Shakespeare era ao mesmo tempo o anunciador não só de um mundo artístico completamente novo, mas também de uma nova cultura. Era ele o Sócrates musicante: "Shakespeare é o poeta da culminação, aperfeiçoa a Sófocles, ele é o Sócrates que cultiva a música" [ist der musiktreibende Sokrates] (NF/FP 1870, 7[131], KSA 7.193).

O significado da simbologia por trás do "Sócrates musicante", Nietzsche esclarece numa passagem de $O$ nascimento da tragédia. Desde quando o instinto e as forças telúricas da Natureza foram aprisionados pelo impulso dialético, escreve o filósofo, se revelou uma 
luta ferina e eterna entre "a consideração teórica e a consideração trágica do mundo". Se houvesse, entretanto, uma força capaz de romper o julgo do instinto imposto pelo racionalismo moderno, pela cultura alexandrina que evoluiu desde o socratismo, e restituísse às forças mágicas da Natureza seu lugar na produção da cultura, o espírito trágico teria mais uma vez renascido. Para uma cultura renascida desse cativeiro do instinto caberia, portanto, "estabelecer como símbolo o Sócrates musicante" (GT/NT \$17, KSA 1.111). É possível ver agora por qual via se chega à afirmação de Brennan no início de seu artigo: Shakespeare, como Lutero, cuja seriedade alemã e o desejo místico de retorno ao infinito encheu seu coração de fúria contra o mundanismo da igreja romana, era o símbolo do despertar do espírito alemão contra o mundo burguês esvaziado e secular. Shakespeare, como símbolo do renascimento do espírito trágico grego, representava uma ruptura com a civilização, uma ponte erguida pelo espírito alemão em direção ao renascimento da tragédia de Ésquilo com o drama musical de Wagner.

Todas essas considerações, no entanto, só aparecem en passant em $O$ nascimento da tragédia, mas isso certamente não acontece em razão de Nietzsche temer aprofundar as contradições com sua doutrina de que só o fundo musical explicaria a grandeza do drama. Quando Nietzsche afirma que o fundo musical é necessário para o drama, o filósofo quer dizer que o inconsciente, que as forças vitais e telúricas da Vontade precisam produzir em imagens sua sabedoria profunda. Que a Vontade, em suma, precisa dar expressão ao inexprimível. O que permite a Nietzsche afirmar, sem contradição, como aponta em anotação escrita entre 1870-1871, que, "como potência dionisíaca suprema, Shakespeare garante o esplêndido desenvolvimento da música alemã" (NF/FP 1870-1, 8[48], KSA 7.242). Algo que Nietzsche certamente pôde concluir a partir do que Wagner defende a esse respeito em sua obra escrita por ocasião das comemorações do centenário de Beethoven. 
Moraes, R. J. B.

Para ser inteiramente iluminado, segundo Wagner em seu texto de 1870, o drama de Shakespeare precisava ser tomado em analogia com outro evento alemão igualmente fundamental: com a música de Beethoven. Nietzsche segue Wagner quando este escreve em seu texto de 1870 que "Shakespeare permaneceu acima de qualquer comparação até que o gênio alemão criou, na figura de Beethoven, um ser que apenas por meio de sua analogia podia ser compreendido" (Wagner, 2010, p.74). Shakespeare, que por tantas décadas tinha permanecido uma incógnita quando comparado a qualquer outro poeta, podia agora ser compreendido à luz de uma analogia com o músico Beethoven. O poeta, argumenta Wagner, criava sempre recorrendo às formas conscientes da individuationis como esquema, enquanto que o compositor, se valendo da linguagem não imagética e não conceitual da música, no limite, pode dispensar a existência do mundo exterior. ${ }^{11}$ Não à toa que o auge da sublimidade da produção de Beethoven ocorre justamente quando se fecha totalmente para ele o sentido do mundo externo, no momento em que o compositor perde a audição (Wagner, 2010, p.52). Embora pertençam a esferas distintas de condições formais de apercepção do mundo, o poeta Shakespeare e o compositor Beethoven, no entanto, coincidiam completamente, pois um estava "contido no outro" (Wagner, 2010, p.75).

Isso fica nítido, ainda de acordo com Wagner, quando tomamos como exemplo a Overture Cariolan de Beethoven, ${ }^{12}$ obra em que o compositor compartilha do mesmo tema que Shakespeare em seu drama de 1607, Cariolano. Nessa obra, o poeta inglês cria em

11 Schopenhauer, a esse propósito, escreve: "o gênio só produz as obras das artes plásticas por uma antecipação premonitória do belo, assim também só se produz as obras de poesia por uma semelhante antecipação do característico, embora, em ambos os casos, ele precise da natureza como um esquema" (Schopenhauer, 2005, p.298). Na mesma direção, também Nietzsche: "à partir de si, a música pode gerar imagens que, então, serão sempre apenas esquemas, como que exemplos de seu conteúdo próprio e universal". (NF/FP 1871, 12[1], KSA 1.360).

12 Trata-se da op.62, escrita originalmente como abertura para a peça do poeta austríaco H..J. von Collin, mas que se torna uma obra autônoma e é representada mais tarde em vários concertos.

$62 \mid$ Cad. Nietzsche, Guarulhos/Porto Seguro, v.42, n.3, p. 45-67, setembro/dezembro, 2021. 
imagens patéticas aquilo que Beethoven, na peça musical, revela por meio do puro universo não conceitual e não imagético do pathos sonoro. Nesse sentido, Shakespeare só pode ser o produtor do mito moderno e como produtor simbólico da ideia do mundo é como uma antena voltada para o mundo exterior que capta o todo íntimo da Natureza, as converte e transmite em uma trama patética: "se designamos a música como revelação da imagem mais íntima de sonho da essência do mundo, podermos considerar Shakespeare como um Beethoven que, desperto, continua sonhando" (Wagner, 2010, p.76).

Wagner retira essa ideia dos Parerga und Paralipomena, de uma interpretação particular do texto schopenhaueriano sobre a vidência. $\mathrm{O}$ fenômeno analisado nesse ensaio de Schopenhauer, ainda segundo Wagner, poderia ser usado como analogia para lançar luz à peculiaridade do músico e das artes sonoras. Na clarividência, o sujeito produz suas imagens de sonho comunicadas ao cérebro a partir da excitação interior do organismo. Durante o sono, no momento em que o cérebro está fechado para o mundo exterior, o clarividente está totalmente entregue a essa vivência interior: "por meio dessa vida íntima que nos aparentamos de modo imediato à natureza inteira, participando de tal modo do essencial das coisas que nessa relação deixa de ter sentido o emprego das formas do conhecimento exterior, o tempo e o espaço" (Wagner, 2010, p.20).

A mensagem de sonho dessa vivência do todo, graças a essa função do cérebro voltada para dentro que Wagner chama de "órgão do sono", é transmitida em imagens como uma espécie de segundo sonho, "imediatamente interior ao despertar, que não é capaz de comunicar o verdadeiro conteúdo do primeiro senão em forma alegórica", pois, como a consciência desperta só conhece as formas puras do princípio de razão, o cérebro voltado para fora "torna necessário aplicar as formas do conhecimento do mundo dos fenômenos segundo o espaço o tempo e, por conseguinte, construir 
Moraes, R. J. B.

uma imagem que se assemelhe às experiências comuns da vida" (Wagner, 2010, p.78-79). Como a consciência voltada para dentro vê algo que não pode ser comunicado por nenhuma linguagem, ela apenas "pode passar à consciência desperta depois de ter sido traduzido na linguagem de um segundo sonho". Esse segundo sonho, que Wagner vai dar o nome de "alegórico", é uma espécie de órgão de comunicação por meio do qual a vontade cria imagens imediatas de sua própria contemplação de si. Tudo isso que descreve um certo sonambulismo do clarividente que produz em imagens projetadas para fora, mas que têm sua origem no mundo interior da vontade (Wagner, 2010, p.26).

Esse estado do clarividente é análogo ao do músico que desperto traduz sua vivência interior em som. Nesse sentido, a música é como um órgão de comunicação que "se de um lado está voltado para a contemplação interior, de outro se relaciona com o mundo exterior que, no estado desperto, se torna de novo vidente, por meio da expressão sedutora e imediata do som" (Wagner, 2010, p.26). A analogia se aplica também a Shakespeare, o produtor do mito moderno que aperfeiçoa o que era precário em Sófocles e com isso seu segredo está por fim revelado. Em Shakespeare, conclui Wagner, "encontramos o vidente e o encantador que faz aparecer, em virtude de sua intuição profunda, diante de seus olhos despertos e dos nossos, figuras humanas de todos os tempos que parecem viver realmente diante de nós" (Wagner, 2010, p.78). Nesse mesmo sentido é que Nietzsche vai dizer que a tragédia, como obra de um clarividente, produz em imagem e diálogo o que tem origem na música, nos motivos internos e inauditos da Vontade e as projeta no mundo exterior como "história de uma série de afetos". ${ }^{13}$

Tudo isso mostra que a projeção de "imagens musicais", sem necessidade propriamente da música, não está em contradição com

13 Conforme Nietzsche define a tragédia em fragmento: "A tragédia - a história como uma série de afetos" ["Die Tragödie — Geschichte als Reihe von Affekten"] (NF/FP 1871, 9[125] KSA 1.320).

64 | Cad. Nietzsche, Guarulhos/Porto Seguro, v.42, n.3, p. 45-67, setembro/dezembro, 2021. 
o que Wagner pensava a propósito do drama inspirado na filosofia da música de Schopenhauer. Com isso, é provável que Nietzsche tenha deixado de incluir, em $O$ nascimento da tragédia, maiores considerações acerca do papel revolucionário de Shakespeare por receio de repetir o que já tinha sido desenvolvido por Wagner em Beethoven, pois, como o próprio Nietzsche deixa anotado em fragmento escrito entre os anos de 1870 e 1871, “o drama de Shakespeare como consequência da Tragédia grega" constava entre as coisas que ele tinha aprendido com Wagner (NF/FP 1870-1, 8[48], KSA 7.241). Nesse mesmo fragmento, o drama de Shakespeare será apontado no contexto de um "chamamento aos alemães" do mesmo modo que Beethoven é apresentado por Wagner em seu texto escrito em homenagem ao centenário do compositor. Assim como Shakespeare tinha feito irromper novamente o mito em meio ao teatro burguês moderno, Beethoven, com suas melodias, tinha retirado a música de seu compromisso com a civilização. Justamente o que, a juízo de Nietzsche, Wagner tinha explanado tão bem e que o tinha feito ver "o autêntico feito de Beethoven" (BVN 1870, 108) ${ }^{14}$ como uma verdadeira cruzada do espírito alemão contra a visão alexandrina do mundo que vai culminar no projeto wagneriano de Bayreuth. Não por outro motivo Wagner será apontado por Nietzsche, ao lado de Schiller, com a ideia de educação estética como primado da arte na edificação de um novo homem, como os precursores da busca por uma cultura segundo o espírito trágico de Shakespeare e Beethoven (NF/FP 1871, 9[147], KSA 7.329).

14 Carta a Wagner de 10 de novembro de 1870. Sobre o modelo de referência, utilizo o mesmo da versão digital da plataforma Nietzsche Source, BVN (sigla para Briefe von Nietzsche), "ano" e "número da carta". 
Moraes, R. J. B.

\section{A culture for Shakespeare and Beethoven}

Abstract: Shakespeare's fundamental importance to the arts and to the German aesthetic debate in the 18th and 19th centuries is well known. The Shakespearean drama was pointed out among the Germans as a veritable cultural revolution, the example of the original genius in which they should follow if they wanted to break free from the bonds of French classicism and to unveil their own originality. This article aims to show how Nietzsche continues this tradition by pointing out Shakespearean drama as an event that had the importance of a cultural revolution among Germans. Shakespeare was the "musician Socrates", the sign of the awakening of tragic genius on German soil.

Keywords: Nietzsche, Shakespeare, Sócrates, musicante, Sófocles.

\section{Referências}

ARISTÓTELES. Poética. Trad. Paulo Pinheiro, São Paulo: Editora 34, 2015.

BRENNAN, K. "Nietzsche's Shakespeare: Musicality and Historicity in The Birth of Tragey", In Memoria di Shakespeare. A Journal of Shakespearean Studies, $1 / 2014$.

GOETHE, J.W. \& SCHILLER, F. Briefwechsel zwischen Schiller und Goethe, Stuttgart: J.G. Cotta, 1881, vol. 1

GOETHE, J.W. "Para o dia de Shakespeare" In: Escritos sobre literatura. Trad. e org. Pedro Süssekind, Rio de Janeiro: 7 Letras, 2000. 2006.

. Os anos de aprendizado de Wilhelm Meister, São Paulo: Edições 34,

KANT, I. Crítica da Faculdade do Juízo. Trad. Valério Rohden e António Marques, Rio de Janeiro: Forense Universitária, 2010.

LESSING, G.E. “Cartas", In: De teatro e literatura. Trad, e org. Anatol Rosenfeld, São Paulo: EPU, 1991.

66 | Cad. Nietzsche, Guarulhos/Porto Seguro, v.42, n.3, p. 45-67, setembro/dezembro, 2021. 
NIETZSCHE, F. A visão dionisíaca do mundo. Trad. e org. Marco S. Pereira \& Fernandes e Maria C. S. Souza, São Paulo: Martins Fontes, 2010.

. Sämtliche Werke. Kritische Studienausgabe (KSA: 15 vols.). Hrsg. Von G. Colli und M. Montinari. Berlin/New York: de Gruyter, 1988.

. Digitale Kritische Gesamtausgabe von Nietzsches Werken und Briefen. Edição organizada por Paolo D’Iorio, baseada na edição crítica de G. Colli e M. Montinari e publicada pela Nietzsche Source. Edição eletrônica. 1967. Disponível em <http://www.nietzschesource.org/\#eKGWB>, acesso em 01/05/2021.

. Introdução ao estudo dos diálogos de Platão. Trad. Marcos Sinésio P. Fernandes/Francisco J. D. de Moraes, São Paulo: Martins Fontes, 2019.

. Introdução à tragédia de Sófocles. Trad. Marcos Sinésio P. Fernandes, São Paulo: Martins Fontes, 2014.

. O Nascimento da Tragédia. Trad. J. Guinsburg, São Paulo: Cia das Letras, 1999.

SCHOPENHAUER, A. O mundo como Vontade e Representação. Trad. Jair Barboza, São Paulo: UNESP, 2005.

WAGNER, R. A obra de arte do futuro. Trad. Jose M. Justo, Lisboa: Antígona, 2003. . Beethoven. Leipzig: Verlag von E. W. Fritzsch, 1870. . Beethoven. Trad. Ana Hartmann, Rio de Janeiro: Zahar, 2010.

. Oper und Drama. Leipizig: Verlag Buchhandlung von J.J Weber, 1869. 1878.

. "Was ist deutsch", Bayreuther Blätter, Chemnitz: Ernst Schmeitzner,

Enviado: 29/12/2020

Aceito: 15/04/2021 